\title{
PELATIHAN SABLON MANUAL UNTUK KREATIFITAS SISWA PADA SMA BUDHI LUHUR PEKANBARU
}

\author{
Atmam*1, Usaha Situmeang $^{2}$, Hazra Yuvendius ${ }^{3}$ \\ ${ }^{1,2,3}$ Program Studi Teknik Elektro, Fakultas Teknik, Universitas Lancang Kuning \\ Jl. Yos Sudarso km. 8 Rumbai, Pekanbaru, Telp. (0761) 52324 \\ E-mail : atmam@unilak.ac.id
}

\begin{abstract}
Budhi Luhur High School (SMA) Pekanbaru is one of high schools in Pekanbaru, Riau Province. The vision of Budhi Luhur High School Pekanbaru is noble, faithful and devoted and Malay culture with one of the vision indicators of academic and non-academic achievement. The facilities and infrastructure owned by Budhi Luhur High School to support the learning process are integrated laboratories and computers. The problem that occurs is the level of knowledge and skills of Pekanbaru Budhi Luhur High School students in mastering the non-academic fields of students is very minimal, caused by a lack of non-academic activities associated with increasing student creativity. Looking at these conditions, efforts are needed to provide knowledge and skills in the field of non-academics for student creativity and one of them is manual screen printing on cloth media. The results of community service activities are students' knowledge of manual screen printing, $100 \%$ of students already know it with an increase of $90 \%$ and knowledge of the equipment needed in the manual screen printing process of students has increased by $80 \%$. Increased students' knowledge about the process of applying on screen printing screens by $90 \%$ and students already know the removal process of manual screen printing films with an increase of $80 \%$.
\end{abstract}

Keywords - Non-academic fields, manual screen printing, screen printing

\section{Abstrak}

Sekolah Menengah Atas Budhi Luhur (SMA) Pekanbaru adalah salah satu sekolah menengah di Pekanbaru, Provinsi Riau. Visi dari SMA Budhi Luhur Pekanbaru adalah berbudi pekerti luhur, beriman dan bertaqwa serta berbudaya melayu dengan salah satu indikator visi berprestasi dibidang akademik dan non akademik. Sarana dan prasarana yang dimiliki SMA Budhi Luhur untuk mendukung proses pembelajaran adalah laboratorium terpadu dan komputer. Masalah yang terjadi adalah tingkat pengetahuan dan keterampilan siswa SMA Budhi Luhur Pekanbaru dalam penguasaan bidang non-akademik siswa sangat minim, disebabkan oleh kurangnya kegiatan non akademik terkait dengan peningkatan kreativitas siswa. Melihat kondisi ini, diperlukan upaya untuk memberikan pengetahuan dan keterampilan di bidang non-akademik untuk kreativitas siswa dan salah satunya adalah sablon manual pada media kain. Hasil kegiatan pengabdian masyarakat adalah pengetahuan siswa tentang sablon manual, 100\% siswa sudah mengetahuinya dengan peningkatan $90 \%$ dan pengetahuan tentang peralatan yang dibutuhkan dalam proses sablon manual siswa meningkat sebesar $80 \%$. Peningkatan pengetahuan siswa tentang proses pengafdrukan pada screen sablon sebesar $90 \%$ dan siswa sudah mengetahui proses penghapusan film sablon manual dengan peningkatan $80 \%$.

Kata kunci-Bidang non akademik, Sablon manual, Screen Sablon

\section{PENDAhULUAN}

Sekolah Menengah Atas (SMA) Budhi Luhur Pekanbaru merupakan salah satu sekolah menengah atas swasta yang berdiri pada tanggal 16 Desember 1988 yang beralamat di jalan Paus Ujung Kecamatan Rumbai Pesisir, Kota Pekanbaru Provinsi Riau. Visi dari SMA Budhi Luhur Pekanbaru adalah berbudi pekerti luhur, beriman dan bertaqwa serta berbudaya melayu dengan salah satu indikator visi berprestasi dibidang akademik dan non akademik. Status akreditasi SMA 
Budhi Luhur Pekanbaru saat ini adalah berakreditasi B. Sarana dan prasarana yang dimiliki SMA Budhi Luhur untuk mendukung proses pembelajaran adalah laboratorium terpadu dan komputer.

Sesuai dengan indikator dari SMA Budhi Luhur Pekanbaru berprestasi dibidang akademik dan non akademik, yang berarti siswa harus memiliki pengetahuan dan keterampilan. Persoalan pengetahuan dan keterampilan dari siswa SMA Budhi Luhur Pekanbaru baik dibidang akademik dan non akademik, erat kaitannya dengan kegiatan yang ada di sekolah tersebut. Saat ini tingkat pengetahuan dan keterampilan khususnya pada bidang non akademik dari siswa SMA Budhi Luhur sangat terbatas sekali. Hal ini disebabkan oleh kurangnya kegiatan yang berhubungan dengan bidang non akademik yang berdampak kepada kurangnya kreatifitas siswa.

Melihat kondisi tersebut, dan juga adanya kondisi keterbatasan kegiatan untuk mengembangkan diri bagi siswa berupa kreatifitas, maka haruslah ada upaya untuk membekali siswa SMA Budhi Luhur Pekanbaru dengan pengetahuan dan keterampilan. Salah satu pengetahuan dan keterampilan yang berhubungan dengan kreatifitas untuk mengembangkan potensi yang ada pada siswa SMA Budhi Luhur Pekanbaru adalah melalui pemberian pelatihan sablon manual dimana proses ini adalah memberikan kreatifitas seni yang dituangkan dalam sebuah media kain. Dari hasil kegiatan ini diharapkan menghasilkan siswa yang mempunyai kreatifitas dan keterampilan dalam sablon manual, sehingga kedepannya dapat membangun komunitas usaha kecil pada masyarakat atau membuka peluang usaha baru sehingga mampu meminimalkan jumlah pengangguran.

\section{METODE}

Metode pelaksanaan yang digunakan dalam kegiatan ini adalah:

1. Penyuluhan.

Memberikan teori tentang sablon manual pada media kain kepada peserta/siswa. Pengetahuan dasar ini sangat penting diketahui oleh para peserta, dikarenakan peserta akan melakukan proses sablon manual. Selanjutnya memberikan teori tentang proses pengafdrukan screen sablon dengan munggunakan bahan-bahan untuk pengafdrukan dan cara dalam pengafdrukan pada screen sablon dan diteruskan dengan penjelasan untuk menghapus screen sablon.

2. Pelatihan

Peserta atau siswa melakukan praktek secara langsung proses pengafdrukan pada screen sablon, proses cetak sablon pada media kain, dan penghapusan film screen sablon yang di dampingi oleh tim pelaksana pengabdian kepada masyarakat.

3. Evaluasi

Teknik mengevaluasi hasil kegiatan adalah dengan memberikan kuisioner kepada peserta yang mencakup seluruh materi sebelum dan sesudah pelatihan.

\section{HASIL DAN PEMBAHASAN}

3.1 Hasil

Kegiatan pengabdian kepada masyarakat ini di ikuti oleh Siswa Sekolah Menengah Atas Budhi Luhur Pekanbaru yang dilaksanakan pada tanggal 18 Desember 2018. Adapun jumlah peserta yang hadir pada kegiatan ini adalah 10 orang dan kuisioner yang diberikan adalah untuk 10 orang. Dari hasil evaluasi pelaksanaan penyuluhan ini melalui Pre-Test dan Post-Test, dapat dikatakan berjalan dengan baik, karena dari peserta yang hadir sebanyak 10 orang menjawab kuisioner yang diberikan.

Peserta menyimak materi yang diberikan oleh tim pengabdian masyarakat tentang sablon manual pada media kain, proses pengafdrukan screen sablon dengan munggunakan bahan-bahan untuk pengafdrukan dan cara dalam pengafdrukan pada screen sablon, proses mencetak pada media kain dan diteruskan dengan penjelasan untuk menghapus screen sablon seperti pada gambar 1. 


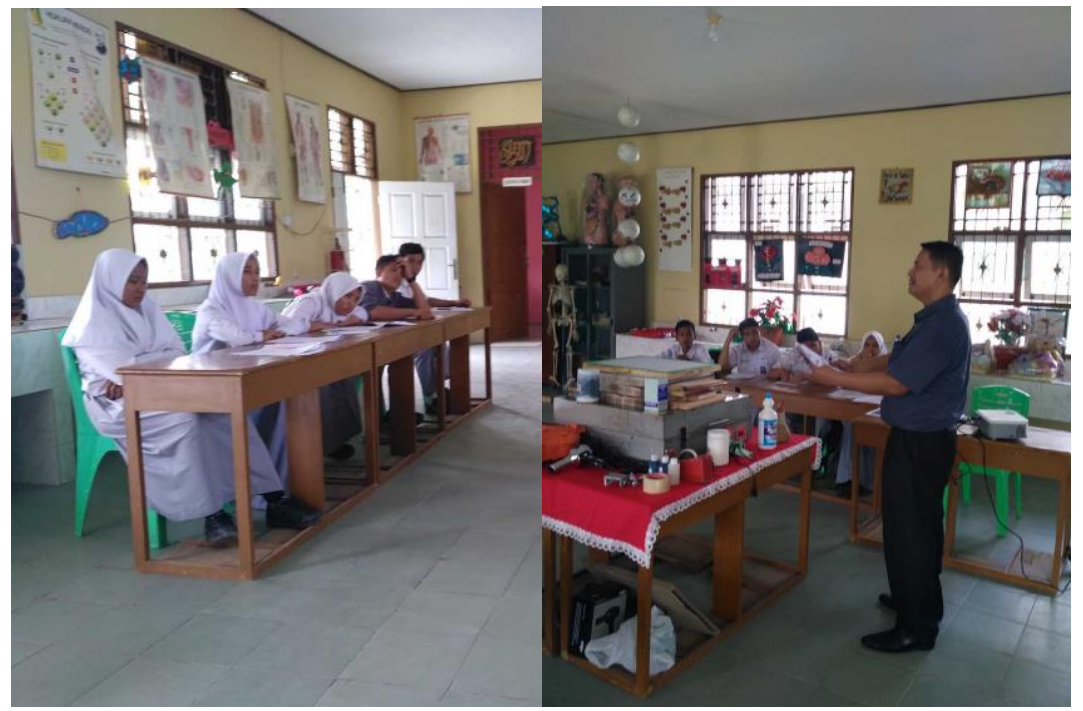

Gambar 1. Peserta pelatihan dan pemberian materi

Setelah diberikan penyuluhan tentang teori sablon manual pada media kain, maka selanjutnya diteruskan dengan melaksanakan praktek secara langsung proses sablon manual yang dimulai dengan proses pengafdrukkan pada screen sablon yang didampingi oleh tim pengabdian kepada masyarakat. Pelaksanaan kegiatan pengafdrukan pada screen sablon bagi peserta atau mahasiswa dibagi menjadi tiga kelompok. Setiap kelompok mendapatkan pengetahuan dan keterampilan tentang proses pengafdrukan screen sablon yang didampingi oleh tim pengabdian kepada masyarakat. Kegiatan pengafdrukan pada screen sablon yang dilakukan oleh peserta seperti pada Gambar 2.

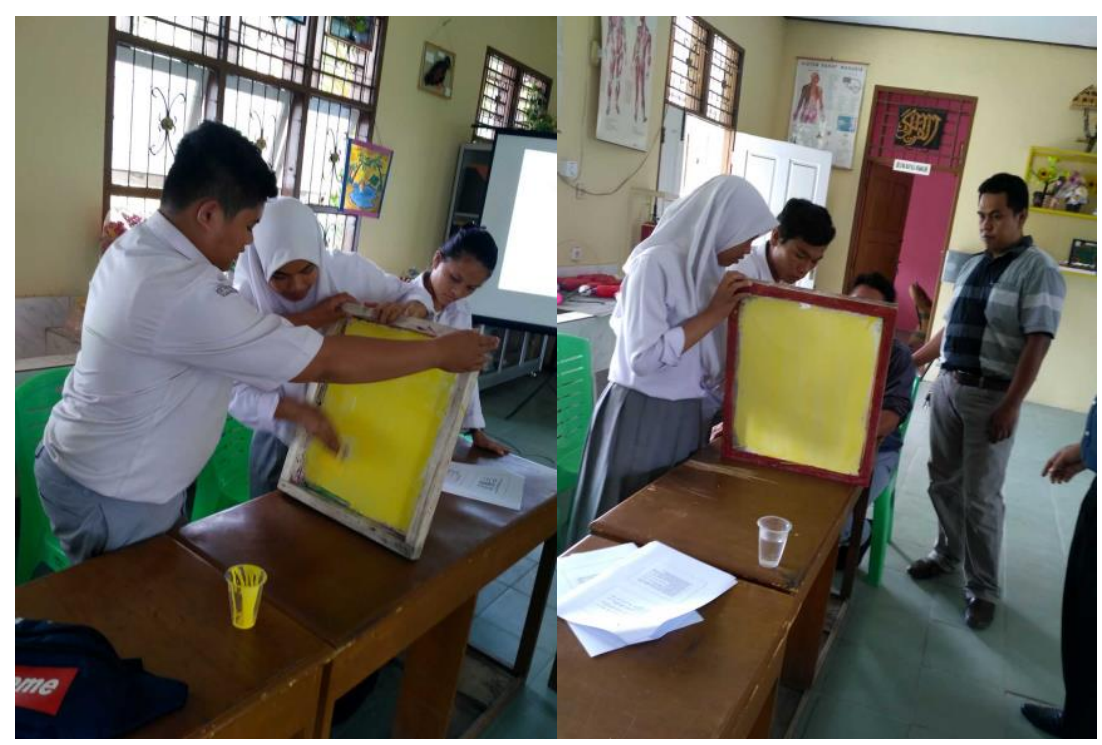

Gambar 2. Peserta melakukan proses pengafdrukan sablon manual didampingi Tim Pengabdian

Proses selanjutnya pada kegiatan pelatihan sablon manual ini adalah proses penyinaran film pada screen sablon yang dilakukan oleh peserta dengan film yang akan dipindahkan sudah dipersiapkan terlebih dahulu. Proses penyinaran film ini dilakukan dengan penyinaran dengan sinar matahari yang dilakukan oleh peserta pelatihan seperti pada gambar 3 dan didampingi oleh tim pengabdian kepada masyarakat. 


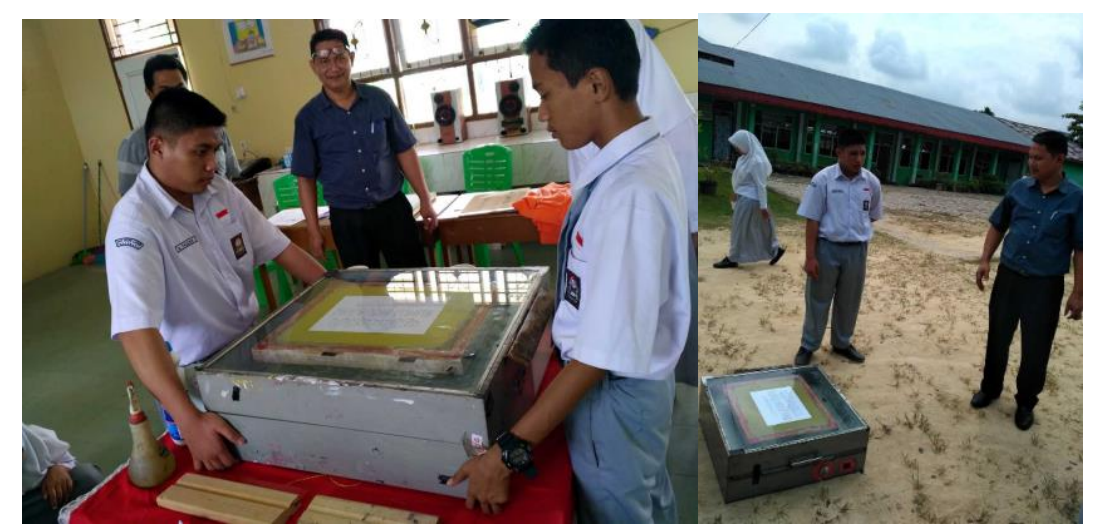

Gambar 3. Peserta melakukan proses penyinaran film pada screen sablon manual dengan sinar matahari

Tahapan berikutnya adalah proses pembersihan atau penyiraman screen sablon yang dilakukan oleh peserta untuk mendapatkan gambar yang jelas dari film yang dipindahkan pada screen sablon dan dilanjutkan dengan pengeringan dari screen sablon menggunakan sinar matahari seperti pada gambar 4.

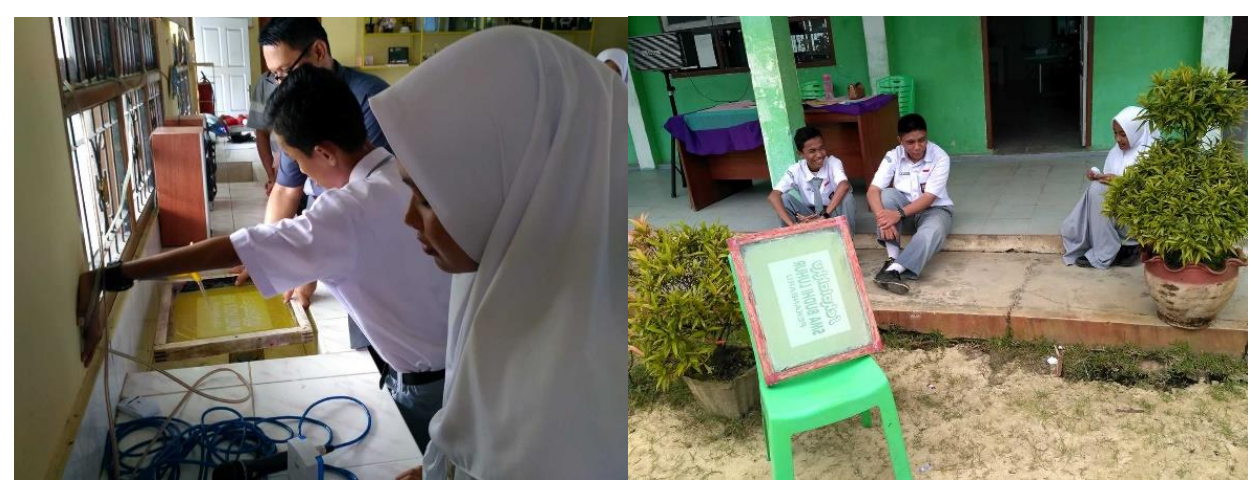

Gambar 4. Peserta melakukan proses penyiraman screen sablon manual dengan air setelah dilakukan penyinaran dan dilanjutkan proses pengeringan screen sablon

Setelah proses pengeringan screen sablon selesai maka screen sablon siap dipakai dan dilanjutkan dengan proses cetak pada media kain yang dilakukan secara bergantian oleh peserta dari tiap kelompok yang didampingi oleh tim pengabdian kepada masyarakat seperti pada gambar 5 .

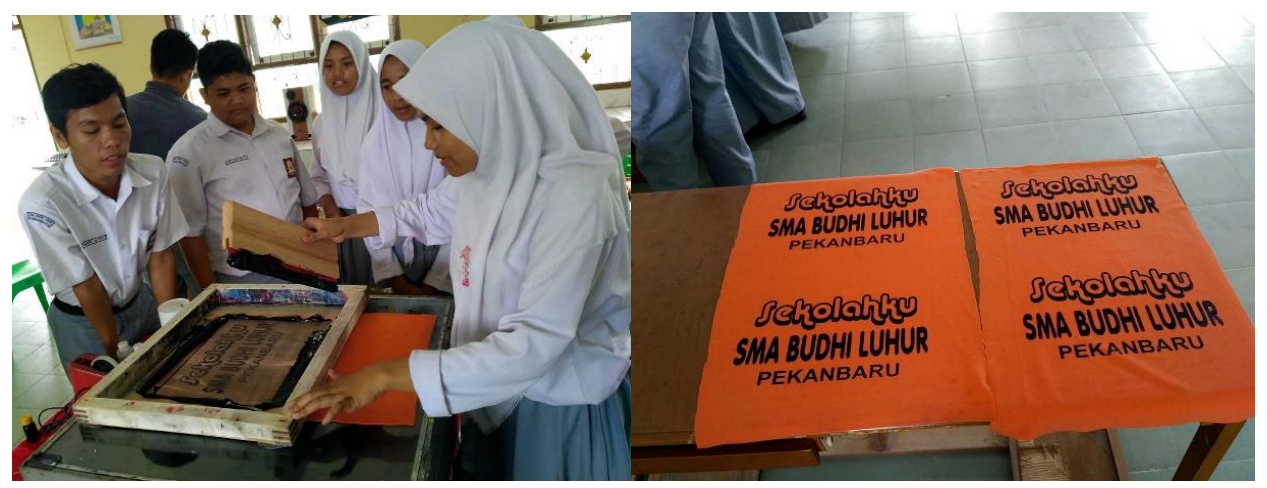

Gambar 5. Peserta melakukan proses cetak screen sablon manual pada media kain

Untuk mengevaluasi kegiatan maka dilakukan dengan pemberian kuisioner kepada peserta dan hasil kuisioner seperti pada tabel 1 dimana setelah selesai ceramah atau pemberian materi dilaksanakan, diadakan kesempatan untuk bertanya atau diskusi, tentang pelatihan sablon manual, kemudian dilanjutkan dengan memberikan visualisasi tentang peralatan-peralatan yang digunakan dalam proses sablon manual oleh tim sebelum dilakukan praktek sablon manual. 
Tabel 2. Hasil Pre-Test dan Post-Test kegiatan

\begin{tabular}{|c|c|c|c|c|c|}
\hline \multirow[t]{2}{*}{ Pertanyaan } & \multicolumn{2}{|c|}{ Pre Test (\%) } & \multicolumn{2}{|c|}{ Post Test (\%) } & \multirow{2}{*}{$\begin{array}{c}\text { Peningkata } \\
\text { n } \\
(\%)\end{array}$} \\
\hline & Ya & Tidak & $\mathrm{Ya}$ & Tidak & \\
\hline $\begin{array}{l}\text { 1. Apakah anda } \\
\text { mengetahui tentang } \\
\text { sablon manual? }\end{array}$ & 10 & 90 & 100 & 0 & 90 \\
\hline $\begin{array}{l}\text { 2. Apakah anda } \\
\text { mengetahui peralatan } \\
\text { yang dibutuhkan dalam } \\
\text { proses sablon manual? }\end{array}$ & 20 & 80 & 100 & 0 & 80 \\
\hline $\begin{array}{l}\text { 3. Apakah anda } \\
\text { mengetahui bahan- } \\
\text { bahan cetak } \\
\text { saring/sablon manual? }\end{array}$ & 0 & 100 & 100 & 0 & 100 \\
\hline $\begin{array}{l}\text { 4. Apakah anda } \\
\text { mengetahui proses } \\
\text { pengafdrukan pada } \\
\text { screen sablon manual ? }\end{array}$ & 0 & 100 & 90 & 10 & 90 \\
\hline $\begin{array}{l}\text { 5. Apakah anda } \\
\text { mengetahui cara } \\
\text { penghapusan film screen } \\
\text { sablon manual? }\end{array}$ & 0 & 100 & 80 & 20 & 80 \\
\hline $\begin{array}{l}\text { 6. Apakah anda puas } \\
\text { terhadap pelaksanaan } \\
\text { acara pelatihan ini ? }\end{array}$ & - & - & 100 & 0 & 100 \\
\hline
\end{tabular}

\subsection{Pembahasan}

Hasil Pre-Test yang dilaksanakan sebelum penyuluhan menunjukkan bahwa peserta atau siswa mengetahui tentang sablon manual sebanyak 9 orang atau $90 \%$ dan $10 \%$ tidak mengetahui tentang sablon manual. Pengetahuan peserta atau siswa tentang peralatan yang dibutuhkan dalam proses sablon sebesar $80 \%$ peserta yang mengetahui dan $20 \%$ tidak mengetahui. Hal ini dikarenakan siswa tidak pernah mengetahui tentang sablon manual dan peralatan sablon manual yang dibutuhkan.

Untuk pertanyaan kuisioner : "Apakah anda mengetahui bahan-bahan cetak saring/sablon manual", $100 \%$ peserta (10 orang) menjawab tidak mengetahui tentang bahan-bahan cetak saring atau sablon manual. Selanjutnya, pertanyaan: "Apakah anda mengetahui proses pengafdrukan pada screen sablon manual", semua peserta menjawab menjawab "Tidak" sehingga dapat dipresentasikan bahwa 100\% peserta tidak mengetahui tentang proses pengafdrukan pada screen sablon manual. Kondisi ini disebabkan karena kegiatan sablon manual ini baru pertama kali dilakukan di SMA Budhi Luhur Pekanbaru.

Dari pertanyaan : "Apakah anda mengetahui cara penghapusan film screen sablon manual". Hasil yang diperoleh bahwa seluruh peserta (10 orang) menjawab "Tidak". Secara persentase bahwa $100 \%$ peserta tidak mengetahui proses sablon, pencetakannya dan juga proses penghapusan film dari screen sablon manual setelah dilakukan proses pencetakan. Pengetahuan dan keterampilan ini memang tidak dimiliki oleh siswa karena kegiatan ini baru pertama kali dilakukan di sekolah ini.

Hasil Post Test yang dilaksanakan setelah penyuluhan dan pelatihan menunjukkan bahwa pengetahuan peserta tentang sablon manual sudah menunjukkan perubahan dari tidak mengetahui (90\%) menjadi mengetahui (100\%) dan terjadi peningkatan 90\%. Pengetahuan tentang peralatan yang dibutuhkan dalam proses sablon manual, juga sudah mengalami peningkatan yaitu $80 \%$ peserta sudah mengetahui dimana awalnya hanya $20 \%$ peserta yang mengetahuinya. 
Selanjutnya dari pertanyaan tentang: Apakah anda mengetahui bahan-bahan cetak saring/sablon manual?, dari jawaban yang diberikan $100 \%$ sudah mengetahuinya dan terjadi peningkatan sebesar $100 \%$. Untuk pertanyaan: "Apakah anda proses pengafdrukan pada screen sablon manual?" dari jawaban yang diberikan $90 \%$ sudah mengetahuinya dan terjadi peningkatan sebesar 90\%. Dari pertanyaan tentang : "Apakah anda mengetahui cara penghapusan film screen sablon manual?" telah terjadi peningkatan $80 \%$ dimana awalnya seluruh peserta atau siswa tidak mengetahui cara menghapus film screen sablon manual

Untuk tingkat keberhasilan dan kepuasan dari acara pengabdian masyarakat ini tentang Pelatihan Sablon Manual Untuk Kreatifitas Siswa Pada SMA Budi Luhur Pekanbaru, 100\% peserta menyatakan puas dengan menjawab "Ya" pada lembar kuisioner post-test.

\section{KESIMPULAN}

1 Pengetahuan peserta tentang sablon manual, 100\% peserta sudah mengetahuinya dengan peningkatan sebesar $90 \%$ serta pengetahuan tentang peralatan yang dibutuhkan dalam proses sablon manual dari peserta terjadi peningkatan sebesar $80 \%$.

2 Peningkatan pengetahuan peserta tentang proses pengafdrukan pada screen sablon sebesar $90 \%$ dan peserta sudah mengetahui proses penghapusan film dari screen sablon manual dengan peningkatan sebesar $80 \%$.

\section{SARAN}

1 Dari hasil kegiatan penyuluhan dan pelatihan diharapkan peserta dapat mempelajari dan melatih ulang tentang proses sablon manual khususnya cara pengafdrukkan film sablon dan proses cetak pada media kain.

2 Dari hasil kegiatan, diperlukan penyuluhan dan pelatihan yang sama untuk siswa SMA Budhi Luhur secara berkesinambungan.

\section{UCAPAN TERIMA KASIH}

Penulis mengucapkan terima kasih kepada semua pihak yang telah memberi dukungan financial terhadap kegiatan ini.

\section{DAFTAR PUSTAKA}

[1] Bakhtiar, 2012, Perancangan Alat Penyinaran Screen Sablon PCB dengan Pengaturan Intensitas Cahaya Berbasis Mikrokontroller AT89S52, Jurnal Litek (ISSN: 16938097) Volume 9 Nomor 2, September 2012: hal. 119123.

[2] Febri Rahmi, 2012, Pelatihan Kewirausahaan Bidang Usaha Sablon, Pemasaran dan Manajemen Keuangannya, Lembaga Pengabdian Masyarakat Universitas Islam Negeri Sultan Syarif Kasim Riau Pekanbaru.

[3] Grace Christina, 2013, Pengelolaan dan Pengembangan Usaha Sablon Pada CV.Celcius di Solo (Studi Pada Aspek Sumber Daya Manusia), Jurnal Agora, Vol. 1, No. 1, 2013.

[4] Risnaningsih, 2013, Pelatihan dan Pendampingan Usaha Mikro Dhi sablon \& Printing dan The Joker's Sablon \& Offset di Malang, Jurnal Dedikasi, ISSN 1693-3214, Volume 12, Mei 2015. 